\title{
The Role of Health Education on Emerging Diseases: A Systematic Review
}

Mahnaz Solhi ${ }^{1}$, Mitra Abolfathi ${ }^{2}$, Fatemeh Darabi ${ }^{3}$, Nasim Mirzaei ${ }^{4}$ and Naila Nejad Dadgar ${ }^{5}$

${ }^{1}$ Department of Health Services and Health Education, School of Health, Iran University of Medical Sciences, Tehran, Iran

${ }^{2}$ Department of Health Education and Health Promotion, School of Health, Iran University of Medical Sciences, Tehran, Iran

${ }^{3}$ Department of Public Health, Asadabad Medical Sciences Faculty, Hamadan University of Medical Sciences, Hamadan, Iran

${ }^{4}$ Department of Health Education and Health Promotion, School of Health, Iran University of Medical Sciences, Tehran, Iran

${ }^{5}$ Department of Health Education and Health Promotion, School of Health, Hamedan University of Medical Sciences, Iran

"Corresponding author: Mitra Abolfathi, Department of Health Education and Health Promotion, School of Health, Iran University of Medical Sciences, Tehran, Iran, Tel: 0021696704740; E-mail: Mabolfathi74@yahoo.com

Rec date: August 16, 2017; Acc date: September 25, 2017; Pub date: September 28, 2017

Copyright: (C) 2017 Solhi M, et al. This is an open-access article distributed under the terms of the Creative Commons Attribution License, which permits unrestricted use, distribution, and reproduction in any medium, provided the original author and source are credited.

\section{Abstract}

Context: The purpose of this study is to review the studies that have used educational intervention in the field of emerging infectious diseases, based on methods, application of models, and theories of health education and health promotion and the effect of interventions on prevention and reducing the incidence of these diseases.

Evidence acquisition: Electronic search of databases was performed using the key words in English and Persian. Databases reviewed were, Scientific Information Database (SID), Iran Medex, PubMed, Ebsco, Scopus, Index Copernicus and Cochrane. The databases search was conducted from October 2016 to July 2017.

Results: Interventions to Emerging diseases were divided into two types based on use of models and theories of health education and without use of models and theories of health education. In the 16 articles reviewed, 7 studies were conducted based on theories and models of health education, and 9 studies did not use theories and models of health education.

Conclusion: Training in the community setting to the analogous groups, time, place, length of intervention and use of modern methods of training, are effective in order to decrease morbidity. Overall, health education, combined with health improvement approaches have a greater impact, in prevention and reducing the incidence of emerging diseases.

Keywords: Education; Emerging infectious; Systematic review

\section{Introduction}

For four decades, until 2000, the world health officials' slogan was health for everyone and they were trying to achieve the eradication of infectious diseases while, the whole world is witnessing developing epidemic and pandemic emerging diseases like SARS (2003), Influenza (H1N1 in 2009, H5N1 in 2003 and H7N9 in 2013), cholera (2010), Ebola in West Africa (2014) and AIDS. Over the past three decades, more than 30 new diseases have threatened the health of the inhabitants of the earth. Some of them were emerging diseases, some were rising diseases and re-emerging ones and some infectious diseases added to the list in the category of disappeared [1]. Regardless of economic status, this epidemic can be a threat to all countries of the world. The human cost and survivors' injuries are unmeasurable. According to the latest report of WHO, $61 \%$ of infectious diseases and $75 \%$ of emerging diseases are zoonotic [2].

Phenomena such as bacterial resistance to antibiotics, the genetic evolution of microbial pathogens, emergence or re-emergence of antimicrobial agents at the time and places where they were not expected have made this semi-bright and perhaps disposing of infectious diseases completely dark. Rising in the speed of human and commercial goods international communication shortened the geographical distances, changes in the production of agricultural goods and livestock methods, regional wars and changes in human lifestyle and ecological changes should be considered as the most important factors of infectious agents returning. In fact, infectious diseases know no physical barriers or geographical boundaries and can be spread very quickly. Gradually, this led to understand the need to prevent and control the spread of them [1].

As we know, re-emerging some infectious diseases, such as tuberculosis and food-borne and emerging diseases and some other infectious diseases such as AIDS and some antibiotic-resistant infections are greatly influenced by individual behavior. Disease prevention is the best and most successful way to fight diseases and restore the health of the community. Nowadays, health and healthy behavior education are known as the best principles of disease prevention in all communities. The World Health Organization mentioned that some of the most important strategies of prevention programs are educational institutions and informing the public, and believes that enabling people to function effectively in a crisis is the important WHO capability [3].

According to studies, the lack of medical and public awareness of the disease in the world is still there. Doctors rarely visit severe infections and vaccines and antibiotics are prescribed for all. Most of these diseases are limited incapacity, while all of them are waiting for 
an opportunity to return. A deeper understanding of cultural, social, and policy factors and intervention strategies helps to inform the community. For example, they have been able to help by tracking back Ebola, provide better information to understand the fears of local people and building trust and increase resistance against Ebola. Interventions epidemic is usually a vertical process like a waterfall, but also need a horizontal approach like a river flowing towards the whole society. This greatly Facilitate protections which is needed for people's involvement. Among the many challenges that have been created by the pandemics the kind of managing information via $t$ Internet, mobile and social media is important. Now, a key element in risk communication is the response to the epidemic of these diseases [2].

The purpose of writing this paper is to analyze studies which have used intervention and programs to prevent emerging infectious diseases. With this study we systematically seek to answer the question whether the use of specific frameworks and models and theories of health education can be effective in reducing risk factors or not?

\section{Methods}

In this systematic review to identify interventional studies in which intervention was main subject to prevent and reduce the incidence of emerging infectious diseases, I started electronic search on databases in both, Farsi and English from September 2016 till July 2017. Persian sites included articles of medical sciences database (Iran Medex) and Scientific Information Database (SID). Some key words like emerging infectious diseases, educational intervention and theories and models of health education were used. Some English websites include Cochrane, Ebsco, Scopus, Index Copernicus and PubMed were also searched by using these key words: Emerging infectious diseases, Educational Intervention, Health education.

Inclusion criteria: Interventional studies that education is their main intervention, target group studies, all persons who may be at the risk of this type of disease and the studies that have been published from July 2010 to July 2015.

Exclusion criteria: Descriptive studies and studies which had educational interventions, or educational interventions that was done for the secondary prevention of patients.

In order to determine the quality of articles, two researchers according to the criteria and design of the studies, reviewed articles and they excluded the articles that didn't have sufficient quality in respect to the objectives of the study. It should be mentioned that we are interested in educational interventions which emphasized to prevent and reduce the incidence of emerging infectious diseases. The reason for choosing this period of time is the significant increase in emerging disease in all around the world. A summary of the features of the studies presented in the tables that were designed by the researchers. The details of the tables are: the study, the author's name, the time of beginning and end of the study, the study target, target groups, the sample size, Investigated disease, the intervention method and the study outcome.

\section{Results}

After searching databases and removing a large number of articles based on the article's title and abstract 2586 (1227 paper from Persian sources and 1359 of English sources) were evaluated. 2194 articles have been excluded because the educational intervention about emerging diseases wasn't undertaken in them (Figure 1). 45 articles were examined exactly and 52 articles of them were included emerging infectious diseases, and 33 ones were descriptive article. 29 articles didn't have appropriate procedures and methods in accordance with our goals. Finally, 16 articles were included in this review. Totally the surveyed articles were divided into 2 groups:

${ }^{\star}$ Studies that the theories and health education models were considered as the base of intervention [4-10].

${ }^{\star}$ The studies that surveyed interventions were carried out without the use of theories and models of health education [11-19].

4 studies were done according to comparing before and after intervention and 12 studies were based on intervention-control. In 6 studies the prevention of flu, in 7 studies prevention of AIDS, and in 3 studies prevention of hepatitis B were examined, (Tables 1 and 2). In addition to behaviors, knowledge, attitudes and opinions in a number of studies were examined.

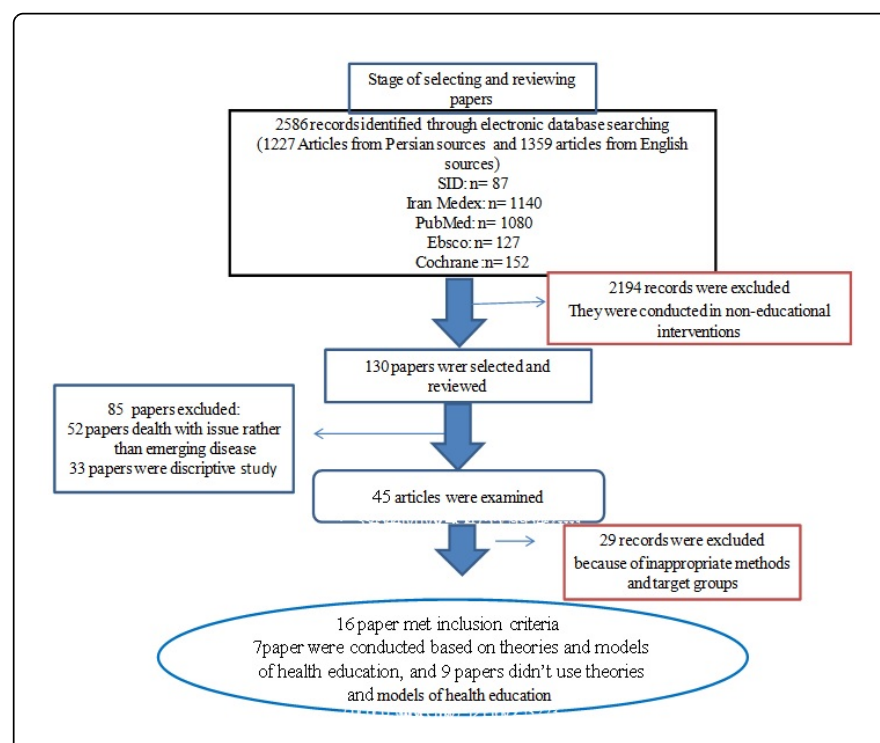

Figure 1: Electronic Resources search results.

\section{Discussion}

\section{Studies based on models and theories of health education}

Seven studies evaluated and surveyed the effect of education according to health educational models and theories. Pay prom et al. in Thailand surveyed high-risk people by increasing the flu vaccination and using health action process approach before and after the procedure [4]. Participants in the intervention process received a leaflet that was written based on the approach. In the leaflet they identified the plan of action by asking about where and how the vaccination would be followed. This intervention caused the greatest changes in the perceptions of risk, outcome expectations, self-efficacy and intention on the situation was comparable. The more attempts were to get the vaccination with a result of changes in expectations, self-efficacy to set the time, transport and planning. No significant difference was observed between the two groups in the vaccinations. Influenza vaccination was predicted directly by self-efficacy and intention. The results indicate that the leaflet theory may be a useful 
one for the individual promotion plans to vaccinate, but we need more studies to confirm these results [4].

A study was conducted to evaluate the intervention and control Web-based intervention to promote hand hygiene on health-care personnel. Educational intervention was presented in 4 sessions of motivational interviewing and self-regulation. Frequent hand washing and theory IDs of planned behavior related to hand washing through online questionnaires were evaluated at 4 weeks and 12 weeks after intervention. Positive intention and attitude towards hand washing increased more than before within 4 weeks in the intervention group. This effect was similar for both sexes. This web-based interventional study offers an effective way to promote hand washing at home. During the flu pandemic of 2010, both groups of participants already exposed to the vast advertising about the need of hand hygiene, with the assumption that intervention may lead to the development of public campaigns. However; future research is needed to determine the effects of intervention on practical infection [5].

Pakpur et al. have done an interventional study to prevent teenager boys from AIDS by using the theory of planned behavior. Educational programs included 5 sessions of group discussion (each 45 to 60minutes) based on the theory of planned behavior and giving purposeful educational booklets. After three months, the results showed that the structure of the theory of planned behavior in the intervention group increased. Educational intervention based on the theory of planned behavior has led to develop the skills of reject and or delay risky proposals in related with AIDS [6].

Soltani et al studied a health belief model survey on female students in order to change their health beliefs about AIDS. AIDS educational content has been designed based on the health belief model in group discussion and answer and question sessions (2 sessions each 1.5 hours) for each group. Totally, 12 sessions were conducted during 2 weeks for the intervention group. 8 weeks after the educational intervention ending the questionnaire has been completed. The scores of all the structures after intervention had significant meaning. The results of this study showed the educational intervention affected students 'beliefs about sexual risk behaviors [7].

Alizadeh Sioki et al. conducted a study in Zahedan. They surveyed the effect of peer education on AIDS preventive behaviors in high school male students using the theory of planned behavior and evaluated its effect by intervention and control method. They used capable students as peer educators and trained them for their duty. Two sessions, each 45 minutes, were conducted on the test group. They completed the same questionnaires again, 45 days after the intervention. The average scores of the groups in terms of knowledge, attitude, practice, behavioral intention, subjective norms, and perceived behavioral control didn't have significant difference. After training, the average scores of all variables in the experimental group compared with the control group significantly increased. Based on this theory, in high school students, according to their specific age requirements, strengthen the knowledge; attitude and avoidance of risky behaviors are essential. It's understood from the results that initial and motivational conditions must be provided and educational program for AIDS preventive health behavior should be compiled in order to achieve significant changes. On the other hand, health education programs should be seriously addressed as apriority in the schools. Therefore, it is recommended that high schools across the country educate about AIDS and these trainings must be embedded in their textbooks. These proceedings will provide a suitable bed for students' awareness promotion and changes in their attitudes and behaviors [8].

Vakili et al. did a study, an intervention and control, on Health communicators in Zanjan and evaluates their communication skills by using health belief model about AIDS. A questionnaire was used to collect data before and 20 weeks after the intervention was completed. They had workshops about HIV and communication skills for the intervention group and AIDS workshop for the control group. In the intervention group, scores between perceived susceptibility, perceived severity and perceived obstacles, before and after the intervention, there was a statistically significant difference, however, in self-efficacy trellises, perceived benefits and behavioral intention, this difference was not significant. Just in the control group the main perceived obstacles structures, showed statistically significant differences and perceived self-efficacy score decreased slightly. Results showed that perceived self-efficacy had the highest predictive behavioral intention. A better effect on the health belief model structures in the intervention group showed the positive role of communication skills training with AIDS. The results of this study emphasize to the need to improve the knowledge and the communication skills of health communicators [9]. Solhi studies in relationships to determine the effect of an educational intervention on empowering high school students in Hamadan city for prevention of smoking [10] and the effects of training programs on promoting the physical activity among school students by using the theory of planned behavior [11].

In Iran, Zamani et al. studied in the intervention and control method over intended preventing behaviors from hepatitis B in female high school students based on the framework of the Health Belief Model. Intervention in the test group included general education and transferring the messages based on the health belief model. In two ways the data have been collected, Self-reporting and observation of the vaccination card which before and three months after intervention in both groups have been done. After the intervention, the scores of behavioral intention and hepatitis $B$ vaccine turns were more than the control group. In this group, 40 percent of changes of intend to do preventive behaviors by perceived susceptibility, self-efficacy and perceived benefits were predictable. According to the findings, if health education helps young girls to understand their susceptibility to hepatitis $B$, the effect of self-efficacy from the prevention of it and the advantages of doing preventive behaviors, probability it increases the decisions to carry out preventive behaviors from hepatitis B [12].

\section{Studies conducted without the use of models and theories of education}

Menabe et al. conducted a study in the intervention and control form over knowledge and behaviors related to avian influenza in high risk farmer's population in Vietnam. The survey of knowledge, attitude and practice was conducted through face to face interviews by health care workers. The interventions showed an increase in the awareness of $\mathrm{H} 5 \mathrm{~N} 1$ by rely on local healthcare workers. The new training program that was considered or this study caused an effect on people's awareness and their early time searching for the health care workers [13].

Taylor et al. did an intervention and control study in order to evaluate the effectiveness of a Hepatitis B instruction in English (ESL) on Asian immigrants. They had 8 training sessions about viral hepatitis $\mathrm{B}$ for intervention group and physical exercise training for the control group. For those who didn't test for hepatitis B, they did 6-month 
follow-up. Just $83 \%$ of people completed the test. Only $11 \%$ of the test in the intervention group and $6 \%$ in the control group were done. The awareness of the students of the intervention group significantly increased. Training instructions had a significant impact on awareness about hepatitis, but it had little effect on hepatitis testing. Future researches should evaluate the effectiveness of instruction for other immigrant groups and health issues, intervention approaches to increase the level of testing for hepatitis in Asian immigrant communities [14].

Stokewell et al. surveyed a study in the intervention and control form in order to find the effect of a flu vaccine SMS reminder for lowincome pregnant women. The intervention group received text messages about flu vaccinations for 5 weeks and 2 reminder messages for the first meeting in September 2011. Both received meeting reminders through the standard phone automatically. The specified end point of the flu shot before or after the childbirth was totally determined at the end of each month (September to December). After determining the gestational age and the number of clinical visits, the women who received the intervention were $30 \%$ more likely to get vaccinated, especially in December. The greatest impact of the intervention was in December. It was $61.9 \%$ in the intervention group in compared to $49 \%$ in the control group. This study showed sending text messages for pregnant women from low-income population increases the influenza vaccination especially; those early messages that were received earlier than the third quarter [15].

Kumar et al. studied a before and after the intervention survey to assess an educational intervention among the barbers to improve their knowledge about AIDS. The intervention included 30-minute lecture, question and answer session, descriptive charts and educational films. The intervention was twice a month and two months after the initial intervention it was repeated. In the third month the barbers 'knowledge was assessed again by using the initial questionnaire. The results of this intervention make us to think and pay attention to media campaigns that can increase the public awareness about blood diseases, and training personnel that may harm people through unsafe operations [16].

Adeomi et al. in the Nigeria surveyed an intervention and control study in order to assess the effectiveness of peer education in improving knowledge, attitudes and sexual behaviors about AIDS among teenagers 10-19 years old. 48 students were trained as peer educators for 2 weeks. The training included lectures, motivational interviewing and plays that consisted of posters, role playing and action performances. To complete the training, they give them leaflet and brochures, too. Two peer educators per school, with the support and encouragement of their teachers, challenged and improved the discussions about AIDS, weekly. 12 weeks after the intervention, they completed the questionnaire. The study found that peer education in improving knowledge, attitudes and preventative behaviors among teenagers is effective. By proper training and supportive supervision, students can be agents of change in the school environment. Teenagers are an important fighting group against AIDS and HIV, so it is recommended that educational programs about AIDS for this target group should be designed according to their specific characteristics. AIDS and HIV education programs should be specified for their age and using peer education should be considered because of its effective consequences [17].

Abramson et al. conducted a study to increase influenza vaccination among primary-care clinics staff by intervention and control method.
Thirteen clinics were selected randomly. The intervention was done by the means of a detailed presentation of a physician, scientific and reminder e-mail distributions and a key figure of available local staff. Based on the results, the immunization in the intervention group increased $25.8 \%$ in compared with the control group (6.6\%). This program developed the effective intervention on increase the low levels of previous vaccination among the staff. This simple intervention could easily be applied in other clinics and organizations in order to improve their personnel's immunization against influenza [18].

In China, Gao et al. did a before and after study to evaluate the impact of school-based educational intervention on knowledge, attitude and behavior of high school students about AIDS. The educational program contained 2 speeches (each one 30 minutes) and a promotional video (45 minutes). After the intervention, all the students' knowledge and positive attitudes about AIDS and HIV were significantly improved. In conclusion, this study suggests that training programs about HIV prevention is effective for teenager students and its success will be definite by consistent training, long-term strategies and following real goals. The decision makers such as school principals and teachers must consider the school education as a solution to prevent the spread of the AIDS epidemic. Curriculum must be developed each semester and the issues should be based on the knowledge and ability to understand of the students in guidance schools and should be different from high schools. They must create the opportunities to equip the students with factual information against AIDS and HIV [19]. Al-Thaqafy et al. did a before and after study, in order to assess the knowledge and attitude of Hepatitis B virus among military personnel in Saudi army. The intervention included a leaflet, group and individual discussions, plays and a speech. The intervention consisted of a three-hour session per day, for 20 days. Knowledge, attitude and practices cores significantly increased after the intervention. Immunization rates rose from $50.5 \%$ to $96.5 \%$ after the intervention. This study confirms the necessity and effectiveness of educational campaigns to improve KAP in the military population. Future studies in this group may have long-term sustainability of such improvements [20].

Hofstetter et al. conducted a study by intervention and control method to assess the impact of the text message reminders with interactive educational information about children flu vaccination in low-income urban population in the United States. They entered the parents of 5462 children aged 6 months to 17 years old from four clinics that were not vaccinated, to the intervention. The texts were sent to eligible parents according to their children's age, the clinic location and random allocation. These texts were classified to three categories: text message reminders with interactive and educational information (1780 children and teenagers); text message reminders with educational information (1760 children and teenagers) and text messages about the usual care (1764 children and teenagers). By using a system of vaccination record that was related to text messaging, the parents in the intervention group received seven text message reminders, weekly. One of the sent messages allowed choosing more information about influenza and influenza vaccination plus interactive educational information. The highest vaccination rates was in thisgroup $38.5 \%$ in compared with the group of educational information text message reminders $35.3 \%$ and the usual care text message reminders $34.8 \%$. Reminder text messages with embedded educational information and options for interaction had a little positive impact on flu vaccination for children in urban, low-income population that were not vaccinated until at autumn [20]. 
Citation: Solhi M, Abolfathi M, Darabi F, Mirzaei N, Dadgar NN (2017) The Role of Health Education on Emerging Diseases: A Systematic Review. J Health Educ Res Dev 5: 229. doi:10.4172/2380-5439.1000229

Page 5 of 7

\begin{tabular}{|c|c|c|c|}
\hline $\begin{array}{l}\text { Location } \\
\text { Author(s) }\end{array}$ & Aim/Target Group & The intervention & The results \\
\hline $\begin{array}{l}\text { Thailand } \\
\text { Pay prom (2011) }\end{array}$ & $\begin{array}{l}\text { Impact of HAPA on intentions to increase flu } \\
\text { vaccine uptake in high risk individuals } 45 \text { - } \\
65 \text { years } \\
\text { (intervention 99-control 102) }\end{array}$ & $\begin{array}{l}\text { Comparing the HAPA-based leaflet with a } \\
\text { standard leaflet Measures of } 2 \text { weeks after the } \\
\text { intervention and vaccination rates during } 2 \\
\text { months }\end{array}$ & $\begin{array}{l}\text { Influenza vaccination was directly predicted by } \\
\text { self-efficacy and intention. }\end{array}$ \\
\hline $\begin{array}{l}\text { UK } \\
\text { Yardley } \\
(2011)\end{array}$ & $\begin{array}{l}\text { Impact of web-based intervention to } \\
\text { promote hand hygiene on TPB (intervention } \\
\text { 324-control 179) }\end{array}$ & $\begin{array}{l}4 \text { sessions of motivational messages and self- } \\
\text { regulation support Hand-washing by online } \\
\text { questionnaires }\end{array}$ & $\begin{array}{l}\text { Hand-washing intentions and positive attitudes } \\
\text { toward hand-washing increased the } \\
\text { intervention group. }\end{array}$ \\
\hline $\begin{array}{l}\text { Iran } \\
\text { Pakpor } \\
\text { (2012) }\end{array}$ & $\begin{array}{l}\text { Impact of educational program based on } \\
\text { TPB on the prevention of AIDS / high school } \\
\text { boys (intervention } 60 \text {-control } 60 \text { ) }\end{array}$ & $\begin{array}{l}\text { Focus group in } 5 \text { session } 45 \text { min and Targeted } \\
\text { leaflet, completing the questionnaires } 3 \text { months } \\
\text { after the intervention }\end{array}$ & $\begin{array}{l}\text { Significant effect on all the constructs in } \\
\text { intervention group }(p<0.001)\end{array}$ \\
\hline $\begin{array}{l}\text { Iran } \\
\text { Vakili (2011) }\end{array}$ & $\begin{array}{l}\text { Impact of communication skills on HBM in } \\
\text { AIDS /Health Volunteers (intervention } 40 \text { - } \\
\text { control 40) }\end{array}$ & $\begin{array}{l}\text { Communication skills training: } 5 \text { Workshop } \\
\text { during } 5 \text { week and } 20 \text { weeks post-intervention } \\
\text { completing the questionnaires }\end{array}$ & $\begin{array}{l}\text { Significant effect on all the constructs. Self- } \\
\text { efficacy as strongest predictor. }\end{array}$ \\
\hline $\begin{array}{l}\text { Iran } \\
\text { Soltani (2014) }\end{array}$ & $\begin{array}{l}\text { Impact of educational program based on } \\
\mathrm{HBM} \text { in AIDS/Students } 14-17 \text { years } \\
\text { (intervention } 77 \text {-control } 72 \text { ) }\end{array}$ & $\begin{array}{l}\text { Lecture, Focus group in } 2 \text { session } 1.5 \text { hours } \\
\text { across } 2 \text { week and } 2 \text { month post-intervention } \\
\text { completing the questionnaires }\end{array}$ & $\begin{array}{l}\text { Significant effect on all the constructs and } \\
\text { knowledge }(p<0.05) .\end{array}$ \\
\hline $\begin{array}{l}\text { Iran } \\
\text { Alizadeh } \\
\text { Siouki } \\
(2013)\end{array}$ & $\begin{array}{l}\text { Impact of Peer education on preventive } \\
\text { behaviors from AIDS based on TPB/high } \\
\text { school (intervention } 77 \text {-control 72) }\end{array}$ & $\begin{array}{l}3 \text { sessions } 90 \text { min for peers Education, } 2 \\
\text { sessions of } 45 \text { minutes for the intervention by } \\
\text { peers, completing the questionnaires after } 45 \\
\text { days }\end{array}$ & Significant effect on all the constructs $(p<0.05)$ \\
\hline $\begin{array}{l}\text { Iran. } \\
\text { Zamani } \\
\text { Alavigeh } \\
(2012)\end{array}$ & $\begin{array}{l}\text { Impact of HBM on behavioral intention in } \\
\text { HBV prevention /adolescent girls } \\
\text { (intervention 128-control 102) }\end{array}$ & $\begin{array}{l}\text { Focus group in } 2 \text { session } 1.5-2 \text { hours lecture: } 9 \\
\text { sessions } 20-30 \mathrm{~min}, 1 \text { month after the } \\
\text { intervention completing the questionnaires }\end{array}$ & $\begin{array}{l}\text { Significant effect on all the constructs } \\
(P=0.000) \text { perceived susceptibility, benefits, } \\
\text { self-efficacy accounted for } 40 \% \text { of variance in } \\
\text { intent to prevent hepatitis } B \text {. }\end{array}$ \\
\hline
\end{tabular}

Table 1: Studies based on theories and models of health education.

\begin{tabular}{|c|c|c|c|}
\hline $\begin{array}{l}\text { Location } \\
\text { Author(s) }\end{array}$ & Aim/Target Group & The intervention & The results \\
\hline $\begin{array}{l}\text { Vietnam } \\
\text { Manabe (2011) }\end{array}$ & $\begin{array}{l}\text { Impact of educational intervention on } \\
\text { awareness and behaviors relating to } \\
\text { Avian Influenza (H5N1) (intervention 300- } \\
\text { control 300) agricultural communities } \\
18-80 \text { years }\end{array}$ & $\begin{array}{l}\text { (KAP) surveys over } 2 \text { days and after } 3 \text { months } \\
\text { intervention. The lectures, leaflet, posters by } \\
\text { local health care }\end{array}$ & $\begin{array}{l}\text { Increasing awareness and reliance on local } \\
\text { health care workers }(p<0.001)\end{array}$ \\
\hline $\begin{array}{l}\text { Nigeria. } \\
\text { Adeomi } \\
(2014)\end{array}$ & $\begin{array}{l}\text { Evaluating the effectiveness of Peer } \\
\text { Education in Improving HIV Knowledge, } \\
\text { and Sexual Behaviors among In-School } \\
\text { Adolescents 10-19 years (intervention } \\
200 \text {-control 200) }\end{array}$ & $\begin{array}{l}48 \text { peer educators (lectures, motivational talks, } \\
\text { audiovisuals, posters, role plays, and practical } \\
\text { demonstration) for two weeks, meeting weekly, } \\
\text { and completing the questionnaires after } 3 \\
\text { months }\end{array}$ & $\begin{array}{l}\text { Increased knowledge and positive attitudes from } \\
50.0 \% \text { to } 86.7 \% \text { and from } 49.0 \% \text { to } 85.6 \% \text {, } \\
\text { respectively }(p<0.05)\end{array}$ \\
\hline $\begin{array}{l}\text { US } \\
\text { Stock well } \\
(2014)\end{array}$ & $\begin{array}{l}\text { Impact of Influenza Vaccine Text Message } \\
\text { Reminders for Urban, Low-Income } \\
\text { Pregnant Women } \\
\text { (intervention 576-control 577) }\end{array}$ & $\begin{array}{l}\text { Sequences of } 5 \text { weekly, text message influenza } \\
\text { vaccinate focus groups. }\end{array}$ & Increased influenza vaccination, $61.9 \%$ \\
\hline $\begin{array}{l}\text { Saudi } \\
\text { Al-Thaqafy } \\
\text { (2012) }\end{array}$ & $\begin{array}{l}\text { Improvement of the low knowledge, } \\
\text { attitude and practice of hepatitis B virus } \\
\text { infection among } 400 \text { Saudi national guard } \\
\text { personnel } \\
\text { (after-before) }\end{array}$ & $\begin{array}{l}\text { Pre- and post-education KAP } \\
\text { Leaflets, group and individual discussions, } \\
\text { visual show, and a lecture. Each session lasted } \\
3 \text { hours at } 20 \text { days }\end{array}$ & $\begin{array}{l}\text { Increased knowledge, positive attitudes and } \\
\text { practice after education } \mathrm{p}<0.001) \text {. }\end{array}$ \\
\hline
\end{tabular}




\begin{tabular}{|c|c|c|c|}
\hline $\begin{array}{l}\text { Israeli } \\
\text { Abramson (2010) }\end{array}$ & $\begin{array}{l}\text { Randomized trial of a program to increase } \\
\text { staff influenza vaccination in primary care } \\
\text { clinics. } 344 \text { (163 intervention - 181control) }\end{array}$ & $\begin{array}{l}\text { A lecture session given by a family physician, } \\
\text { e-mail-distributed literature and reminders, and } \\
\text { a key figure from the local staff during the } \\
2007-2008 \text { influenza seasons. }\end{array}$ & $\begin{array}{l}\text { Immunization rate was } 52.8 \% \text { in the intervention } \\
\text { group compared with } 26.5 \% \text { in the control group } \\
(\mathrm{P}<0.001)\end{array}$ \\
\hline $\begin{array}{l}\text { US } \\
\text { Taylor } \\
(2011)\end{array}$ & $\begin{array}{l}\text { Evaluating the effectiveness of a hepatitis } \\
\text { B English as a second language (ESL) } \\
\text { educational curriculum for Asian } \\
\text { immigrants ( } 80 \text { intervention - } 100 \text { control) }\end{array}$ & $\begin{array}{l}\text { Eighty ELSA classes were randomized to the } \\
\text { hepatitis B curriculum ( } 40 \text { classes) or physical } \\
\text { activity curriculum ( } 40 \text { classes). HBV testing in } \\
\text { the six months following their project class }\end{array}$ & $\begin{array}{l}\text { A meaningful impact on knowledge and a limited } \\
\text { impact on HBV testing levels Nine }(11 \%) \text { of the } 80 \\
\text { experimental group students and } 6(6 \%) \text { of the } \\
100 \text { control group students }\end{array}$ \\
\hline $\begin{array}{l}\text { US } \\
\text { Hofstetter } \\
\text { (2015) }\end{array}$ & $\begin{array}{l}\text { Impact of educational plus interactive text } \\
\text { message reminders on influenza } \\
\text { vaccination. Parents of } 5,462 \text { children } \\
\text { aged } 6 \text { months- } 17 \text { years (before and } \\
\text { after) }\end{array}$ & $\begin{array}{l}\text { Seven text message reminders less than } 160 \\
\text { characters during the of the week during five } \\
\text { weekly, two booster text messages and a } \\
\text { message request additional information }\end{array}$ & $\begin{array}{l}\text { The educational plus interactive text message } \\
\text { arm was vaccinated }(38.5 \%) \text { in the educational- } \\
\text { only text message }(35.3 \% \text {; ) and usual care } \\
(34.8 \%) \text {; }\end{array}$ \\
\hline China. Gao(2012) & $\begin{array}{l}\text { Evaluating the effectiveness of School- } \\
\text { based Education on HIVIAIDS } \\
\text { Knowledge, Attitude, and Behavior among } \\
\text { Secondary School Students (702 } \\
\text { intervention- } 766 \text { control) }\end{array}$ & $\begin{array}{l}\text { Two sections, namely a } 30 \text { minutes lecture and } \\
\text { a } 15 \text {-minute promotional video }\end{array}$ & $\begin{array}{l}\text { Improving awareness and positive attitude after } \\
\text { intervention. }\end{array}$ \\
\hline $\begin{array}{l}\text { Pakistan } \\
\text { Kumar Krishanani } \\
(2014)\end{array}$ & $\begin{array}{l}\text { Impact of educational intervention among } \\
\text { Barbers to Improve Their Knowledge } \\
\text { regarding HIVIAIDS (before-after) } \mathrm{N}=70\end{array}$ & $\begin{array}{l}30-\text { min educational intervention twice one } \\
\text { month and two months after the intervention. } \\
\text { Charts describing and illustrating and } \\
\text { completing the questionnaires two months after } \\
\text { the intervention. }\end{array}$ & $\begin{array}{l}\text { Increasing knowledge to } 43 \% \quad(p<0.001) \\
\text { educational intervention warrant consideration of } \\
\text { activation of mass campaigns }\end{array}$ \\
\hline
\end{tabular}

Table 2: Studies none of theories and models of health education.

\section{Conclusions}

According to the re view of studies that had been done in this regard, it can be said that to prevent and reduce the risk of these disease, we need a continuous training in combination with other methods such as environmental changes. Another finding of this review is that the use of theoretical frame works and models of health education as a means to reduce risk can be effective in achieving the better results. Using standardized health education and national confirmed programs (national program for the prevention from AIDS, influenza, etc.) can increase the effect of these trainings. The way of providing training programs and use of various methods according to the features of the audience will help. For example, to encourage young people to get vaccine, we can use the campaigns. The use of modern methods such as e-learning and web-based education will also have a positive impact on increasing the awareness and behavioral changes. As well, training the homological groups in the community setting increases the effectiveness of training. Totally we can say that health education in combined with approaches to health improvement will have a significant impact on reducing the incidence and prevention of emerging diseases.

\section{Acknowledgments}

The authors acknowledge all research staff including interviewers, data analysts and officials in this study.

\section{References}

1. Hatami H (2014) Textbook of Public Health (3rd edn) Tehran, CA: Arjmand 89-101.

2. Mathis M, Briand S, Prentice T (2015) Emerging and re-emerging infectious threats in the 21st century 90: 217-252.

3. Glanz K, Rimer BK, Viswanath K (2008) Health behavior and health education: Theory, research, and practice. San Francisco, CA: Jossey-Bass.
4. Payaprom Y, Bennett P, Alabaster E, Tantipong H (2011) Using the Health Action Process Approach and implementation intentions to increase flu vaccine uptake in high risk Thai individuals: a controlled before-after trial. Journal of Health Psycholology 4: 492-500.

5. Yardley L, Miller S, Schlotz W, Little P (2011) Evaluation of a Web-based intervention to promote hand hygiene: exploratory randomized controlled trial. Journal of Medical Internet Research 13: E107.

6. Pakpour HA, Mohammadi ZI, Mohammadi ZB (2012) The Impact of Health Education Based on Theory of Planned Behavior on the Prevention of AIDS among Adolescents. Iran Journal of Nursing 25: 1-13.

7. Vakili MM, Hidarnia A, Niknami S, Mousavinasab N (2012) Effect of Communication Skills Training on Health Belief Model Constructs about AIDS in Zanjan Health Volunteers (2010-11). Journal of Zanjan University of Medical Sciences \& Health Services 19: 78-93.

8. Alizadeh Siouki H, Zareban I, Rakhshani F, SHahraki Poor M, Hasanzadeh M, et al. (2013) The effect of peer education on preventive behaviours from aids based on theory of planned behavior in high school second grade students in Zahedan-89. Quarterly of the Horizon of Medical Sciences 18: 232-241.

9. Solhi M, Abasi H, Hazavehei M (2014) Effect of educational intervention on empowerment of high school student in prevention of smoking. Razi Journal of Medical Sciences 21: 118.

10. Mahnaz S, Fazel ZM, Kambiz KS, Mohammad HT, Farzad J (2011) Designing and Implementing Educational Program to Promote Physical Activity Among Students: An Application of the Theory of Planned Behavior. Journal of Gonabad Medical Sciences 18: 1.

11. Zamani Alavigeh F (2012) Assesment of the Health Belief Model effect on Behavioran Intention for Hepatit B Prevention among adolescent girls. Payesh 11: 545-554.

12. Manabe T, Thuy PTP, Van Can V, Takasaki J, Huyen DTT (2011) Impact of educational intervention concerning awareness and behaviors relating to avian influenza (H5N1) in a high-risk population in Vietnam. PloS one 6: e23711.

13. Taylor VM, Gregory Hislop T, Bajdik C, Teh C, et al. (2011) Hepatitis B ESL education for Asian immigrants. J Community Health 36: 35-41.

14. Stockwell MS, Westhoff C, Kharbanda EO, Vargas CY, Camargo S, et al. (2014) Influenza vaccine text message reminders for urban, low-income 
Citation: Solhi M, Abolfathi M, Darabi F, Mirzaei N, Dadgar NN (2017) The Role of Health Education on Emerging Diseases: A Systematic Review. J Health Educ Res Dev 5: 229. doi:10.4172/2380-5439.1000229

Page 7 of 7

pregnant women: a randomized controlled trial. Am J Public Health 104 7-12.

15. Kumar Krishanani M (2014) Educational Intervention among Barbers to Improve Their Knowledge regarding HIV/AIDS: A Pilot Study from a South Asian Country. J Health Popul Nutr. 32: 386-90.

16. Adeomi AA, Adeoye OA, Asekun-Olarinmoye EO, Abodunrin OL, Olugbenga-Bello AI, et al. (2014) Evaluation of the effectiveness of peer education in improving HIV knowledge, attitude, and sexual behaviours among in-school adolescents in Osun State, Nigeria. AIDS Research and Treatment.

17. Abramson ZH, Avni O, Levi O, Miskin IN (2010) Randomized trial of a program to increase staff influenza vaccination in primary care clinics. The Annals of Family Medicine 8: 293-298.
18. Gao X, Wu Y, Zhang Y, Zhang N, Tang J, et al. (2012) Effectiveness of School-based Education on HIV/AIDS Knowledge, Attitude, and Behavior among Secondary School Students in Wuhan, China. PLoS ONE 7: e44881.

19. Al-Thaqafy MS, Balkhy HH, Memish Z, Makhdom YM, Ibrahim A, et al. (2012) Improvement of the low knowledge, attitude and practice of hepatitis B virus infection among Saudi national guard personnel after educational intervention. BMC Research Notes 5: 597.

20. Hofstetter AM, Vargas CY, Camargo S, Holleran S, Vawdrey DK, et al. (2015) Impacting delayed pediatric influenza vaccination: a randomized controlled trial of text message reminders. Am J Prev Med 48: 392-401. 